\title{
$\mathrm{BSCF}$ 계 혼합전도성 공기극의 두께에 따른 고체산화물 연료전지의 전기화학적 특성
}

\author{
정재원 ${ }^{1,2} \cdot$ 유충열 ${ }^{1} \cdot$ 주종훈 ${ }^{1} \cdot$ 유지행 ${ }^{1,2 \dagger}$
}

${ }^{1}$ 한국에너지기술연구원 에너지융합소재연구단, ${ }^{2}$ 과학기술연합대학원 신에너지기술전공

\section{Electrochemical Performance of the Solid Oxide Fuel Cell with Different Thicknesses of BSCF-based Cathode}

\author{
JAEWON JEONG ${ }^{1,2}$, CHUNG-YUL YOO $^{1}$, JONG HOON JOO ${ }^{1}, \mathrm{JI} \mathrm{HAENG} \mathrm{YU}^{1,2 \dagger}$ \\ ${ }^{1}$ Korea Institute of Energy Research. Gajeong-ro 102, Daejeon 305-343, Korea \\ ${ }^{2}$ University of Science and Technology, Gajeong-ro 217, Daejeon 305-333, Korea
}

\begin{abstract}
In order to reduce the costs and to improve the durability of solid oxide fuel cell (SOFC), the operating temperature should be decreased while the power density is maintained as much as possible. However, lowering the operating temperature increases the cathode interfacial polarization resistances dramatically, limiting the performance of low-temperature SOFC at especially purely electronic conducting cathode. To improve cathode performance at low temperature, the number of reaction sites for the oxygen reduction should be increased by using a mixed ionic and electronic conducting (MIEC) material. In this study, anode-supported fuel cells with two different thicknesses of the MIEC cathode were fabricated and tested at various operating temperatures. The anode supported cell with $32.5 \mu \mathrm{m}$-thick BSCFZn-LSCF cathode layer showed much lower polarization resistance than that with $3.2 \mu \mathrm{m}$ thick cahtode and higher power density especially at low temperature. The effects of cathode layer thickness on the electrochemical performance are discussed with analysis of impedance spectra.
\end{abstract}

Key words : Solid Oxide Fuel Cell(고체산화물 연료전지, SOFC), Mixed Ionic Electronic Conducting cathode (혼합전도성 공기극), Oxygen reduction reaction(산소 환원 반응), Oxygen exchange reaction(산소 교환 반응), Electrochemical Impedance Spectroscopy(EIS)

\section{1. 서 론}

고체산화물 연료전지(Solid Oxide Fuel Cell) 는 연 료기체가 소유하고 있는 화학에너지를 전기화학반응 에 의해 직접 전기에너지로 변환시키는 에너지 변환

\footnotetext{
${ }^{\dagger}$ Corresponding author : jhyu@kier.re.kr [ 접수일 : 2013.4.2 수정일 : 2013.4.19 게재확정일 : 2013.4.26 ] Copyright (c) 2013 KHNES
}

장치로 다른 연료전지에 비해 효율이 높고, 별도의 연료개질장치 없이 천연가스 및 바이오매스와 같은 다양한 연료의 사용이 가능하며, 복합 발전이 가능하 다는 장점이 있다. 그러나 높은 작동 온도로 인하여 금속 연결재 및 구성 요소의 제작비용이 높고, 세라 믹 재료간의 반응 문제로 인한 화학적 안정성, 금속 분리판으로부터 $\mathrm{Cr}$ 휘발로 인한 장기적인 성능 저하 등이 해결되어야 할 과제이다. 
이러한 문제를 해결하기 위하여 고체산화물 연료 전지의 작동온도를 $600-800^{\circ} \mathrm{C}$ 로 낮추려는 연구가 계 속되고 있다. 그러나 작동 온도를 낮추면 전해질의 저항이 증가하고, 전극의 촉매 활성을 저하되어 출력 성능이 감소된다. 한편, 비교적 전해질 두께가 얇은 전극지지형 연료전지의 경우 연료전지의 성능은 전 해질의 ohmic 저항보다 공기극의 낮은 촉매 성능으로 인한 분극저항에 의해 좌우된다 ${ }^{1)}$. 특히 $\mathrm{La}_{1-\mathrm{x}} \mathrm{Sr}_{\mathrm{x}} \mathrm{MnO}_{3}$ 같은 전자 전도성만 지닌 공기극을 사용하는 경우, 산소의 환원 반응이 전해질과 공기극의 삼상계면 (triple phase boundary)으로 제한되므로 산소 교환 반응속도가 비교적 느린 낮은 온도영역에서 높은 성 능을 얻기 어렵다 ${ }^{2}$.

이와 달리 공기극 재료를 이온 전도와 전자 전도 를 동시에 나타내는 혼합 전도성 물질을 사용하면 환원반응이 전극입자의 전체 표면에서 일어남으로 써, 양극(공기극)의 과전압을 줄일 수 있으므로 낮은 작동온도에서도 높은 출력성능을 얻을 수 있다 ${ }^{3-5)}$. 혼합전도성 공기극을 사용하면 연료전지의 성능을 증가시킬 수 있는 것은 분명하지만 최적의 반응면적 은 공기극에 사용된 물질의 화학적, 물리적 특성-즉, 혼합전도체에서의 체적확산계수(bulk diffusion coefficient), 표면에서의 이온교환반응 속도(surface exchange reaction rate) 뿐만 아니라 코팅층의 미세구조(입자크 기, 기공률, 두께)에 의해 달라진다 ${ }^{6-8)}$.

본 연구에서는 혼합전도성 공기극의 두께를 달리 한 음극지지형 연료전지를 제작하여 공기극의 두께 가 연료전지의 전기화학적 특성에 미치는 영향을 고 찰하였다.

\section{2. 실험 방법}

음극지지형 단전지를 제조하기 위하여 $\mathrm{NiO}(99.97 \%$, High Purity Chemicals, Japan), Y-안정화 $\mathrm{ZrO}_{2}$ (TZ$8 \mathrm{YS}$, Tosoh, Japan) 및 carbon black 상용 분말을 습 식볼밀에 의해 혼합하였다. 건조된 혼합분말을 디스 크 형태로 일축 가압성형한 후, $1150^{\circ} \mathrm{C}$ 에서 가소결 하여 지지체를 제조하였다. Sc-안정화 $\mathrm{ZrO}_{2}(10 \mathrm{~mol} \%$
$\mathrm{Sc}_{2} \mathrm{O}_{3}-1 \mathrm{~mol} \% \mathrm{CeO}_{2}-\mathrm{ZrO}_{2}$, DKKK, Japan) 전해질을 dip-coating 법으로 증착시켰다. 음극 지지체에 코팅 된 $\mathrm{ScSZ}$ 전해질은 $1000^{\circ} \mathrm{C}$ 에서 열처리 후 공기극과 전해 질의 반응을 차단하기 위해 $\mathrm{Gd}$-첨가 $\mathrm{CeO}_{2}\left(\mathrm{Gd}_{0.1} \mathrm{CeO}_{2-8}\right.$, Anan Kasei, Japan)를 중간층으로 dip-coating 법으로 증착 시킨 후 $1350^{\circ} \mathrm{C}$ 에서 공소결 하였다.

공기극은 전자 전도성과 이온 전도성을 모두 가지 고 있는 혼합전도성(Mixed Ionic Electronic Conducting Ceramic) 페롭스카이트(Perovskite) 산화물 중 고 상반응법으로 합성한 $\mathrm{BSCFZn}\left(\mathrm{Ba}_{0.5} \mathrm{Sr}_{0.5} \mathrm{Co}_{0.8} \mathrm{Fe}_{0.1} \mathrm{Zn}_{0.1}\right.$ $\left.\mathrm{O}_{3-\delta}\right)$ 과 상용 $\mathrm{LSCF}\left(\mathrm{La}_{0.6} \mathrm{Sr}_{0.4} \mathrm{Co}_{0.2} \mathrm{Fe}_{0.8} \mathrm{O}_{3-8}\right.$, Kceracell, Korea)를 혼합하여 사용하였다. 공기극 역시 dipcoating 법을 사용하였으며, 공기극 두께의 조절을 위 하여 dip-coating용 slurry에 첨가되는 바인더(Polyvinyl butyral, ACROS, BEL)를 분말 질량 대비 $8 \%$ 와 $20 \%$ 로 각각 다르게 하였다. 공기극은 4회에 걸쳐 상온에 서 코팅 및 건조를 반복한 후 $950^{\circ} \mathrm{C}$ 에서 3 시간 동안 열처리 하였다.

제조된 단전지의 출력 성능은 $800^{\circ} \mathrm{C}-650^{\circ} \mathrm{C}$ 온도 범위에서 $50^{\circ} \mathrm{C}$ 간격으로 측정하였다. 연료극과 공기 극에 수소가스와 $(99.9 \%)$ 와 합성 공기(산소 $21 \%$, 질 소 $79 \%$ )를 각각 $100 \mathrm{~mL} / \mathrm{min}$ 의 유량으로 공급하였다. Galvanostat(Solartron 1287A, UK)을 사용하여 전류 -전압 특성을 측정하였으며, Impedance/Gain-Phase Analyzer(Solartron 1260A, UK)를 사용하여 교류 임 피던스를 측정하였다. A.C. amplitude는 $50 \mathrm{mV}$ 로 고 정하였고 주파수를 $0.1 \mathrm{~Hz}$ 에서 $10 \mathrm{MHz}$ 범위로 변화 시켰다.

\section{3. 결과 및 고찰}

\section{1 바인더 함량과 공기극 두께}

Fig. 1은 슬러리의 바인더 함량에 따라 공기극이 각각 다른 두께로 코팅 된 단전지의 단면 사진이다. Fig. 1(a)와 (b)의 미세구조를 비교해보면 공기극과 전해질의 반응을 차단하기 위한 $\mathrm{GDC}$ 중간층 및 $\mathrm{ScSZ}$ 전해질의 두께가 거의 같다는 것을 확인하였 

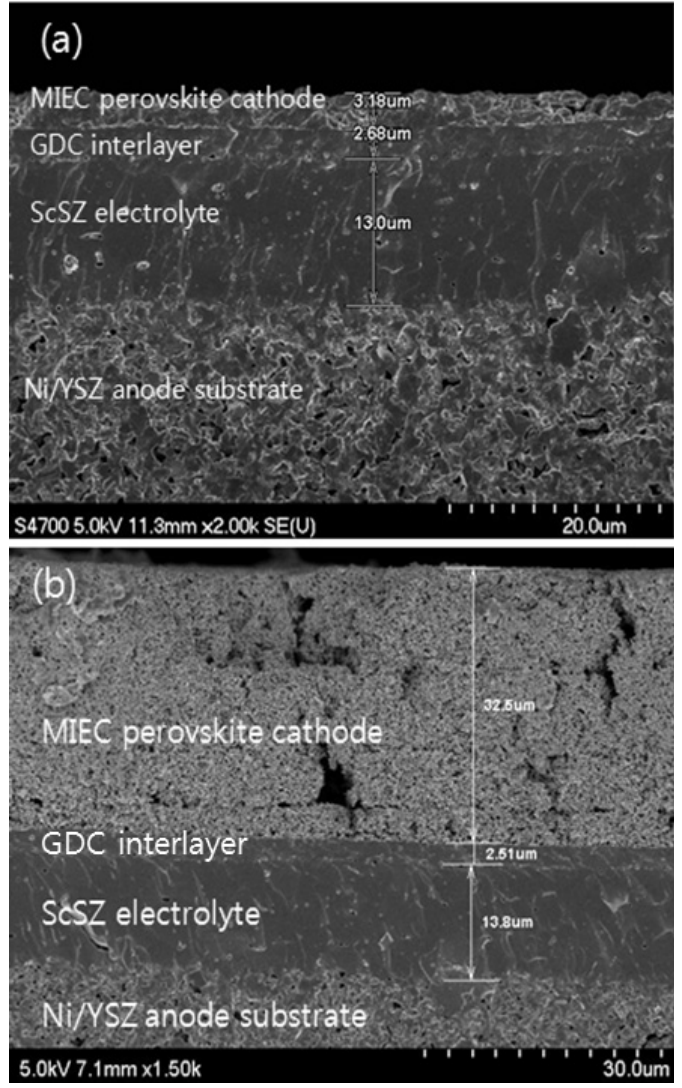

Fig. 1 SEM Microstructure of anode-supported fuel cells (NiOYSZ/ScSZ/GDC/BSCFZn-LSCF) with cathode layers coated from slurries with (a) $8 \%$ and (b) $20 \%$ PVB

다. 공기극은 바인더의 첨가량만 다르고 동일한 조건 으로 코팅 하였는데, 바인더가 분말 질량 대비 $8 \%$ 첨가된 slurry로 코팅 된 공기극은 두께가 약 $3.2 \mu \mathrm{m}$ 로 매우 얇게 코팅되었지만 $20 \%$ 가 첨가된 slurry로 코팅 된 공기극의 두께는 $32.5 \mu \mathrm{m}$ 로 10 배 정도 두껍 게 코팅 된 것을 확인 할 수 있었다. 이는 바인더의 함량에 따라 코팅된 슬러리의 점도가 달라지고, 1회 코팅-건조에 따른 공기극의 증착두께가 달라지는 것 으로 생각된다.

\section{2 공기극 두께와 작동온도에 따른 전기화학적 특성}

공기극의 두께와 작동온도에 따른 단전지의 출력 특성을 비교하기 위하여 $800^{\circ} \mathrm{C}-650^{\circ} \mathrm{C}$ 의 온도 범위
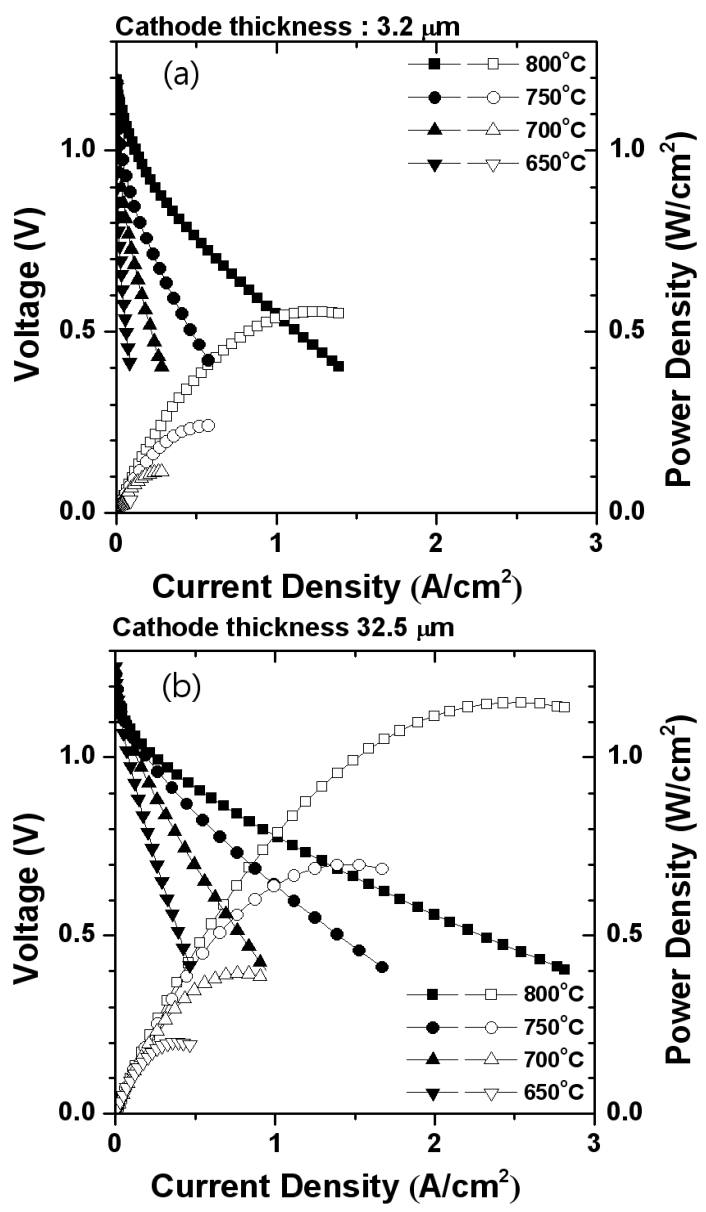

Fig. 2 Power density and current density of single cell with different cathode thickness. (a) $3.2 \mu \mathrm{m}$ thick cathode layer, (b) $32.5 \mu \mathrm{m}$ thick cathode layer

에서 $50^{\circ} \mathrm{C}$ 간격으로 전류-전압 곡선을 측정하였다 (Fig. 2). 공기극의 두께가 $32.5 \mu \mathrm{m}$ 인 단전지의 출력 성능은 $800^{\circ} \mathrm{C}$ 에서 최고 출력 $1.15 \mathrm{~W} / \mathrm{cm}^{2}$ 을 나타낸 반 면, 공기극의 두께가 $3.2 \mu \mathrm{m}$ 인 단전지는 $0.56 \mathrm{~W} / \mathrm{cm}^{2}$ 으로 약 절반 이하의 성능을 보였다. 공기극의 두께 는 온도 감소에 따른 최대 출력의 변화크기에도 영향 을 주었다. 공기극 두께가 $32.5 \mu \mathrm{m}$ 인 단전지는 $800^{\circ} \mathrm{C}$ 에서 $650^{\circ} \mathrm{C}$ 로 측정 온도가 낮아질 때 최고 출력이 $1.15 \mathrm{~W} / \mathrm{cm}^{2}$ 에서 $0.20 \mathrm{~W} / \mathrm{cm}^{2}$ 으로 약 $72 \%$ 감소한 반면, 공기극 두께가 $3.2 \mu \mathrm{m}$ 인 단전지는 $0.56 \mathrm{~W} / \mathrm{cm}^{2}$ 에서 $0.04 \mathrm{~W} / \mathrm{cm}^{2}$ 로 $93 \%$ 가량 감소하였다.

공기극의 두께가 작동온도 감소에 따른 전기적인 

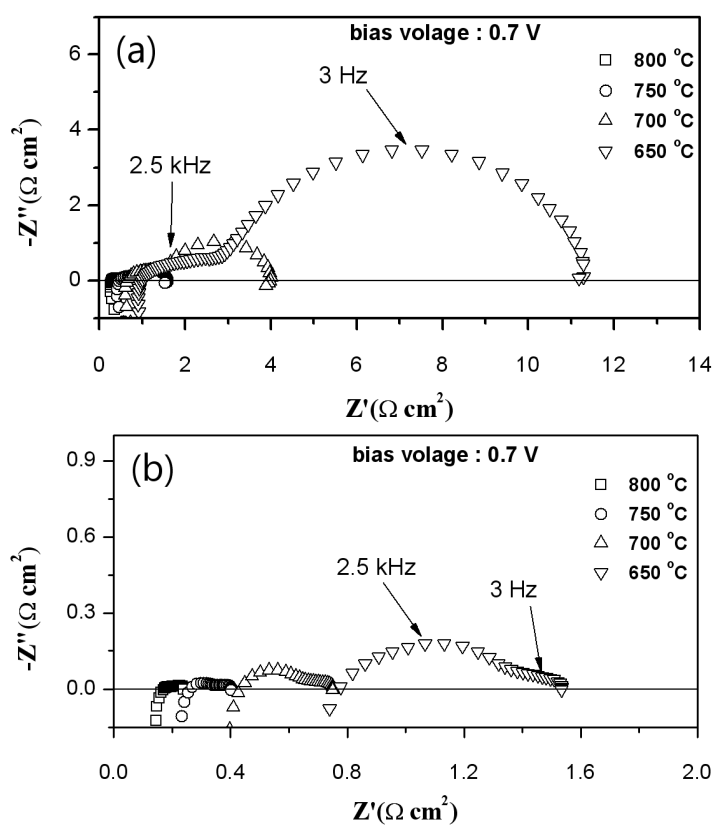

Fig. 3 Impedance spectra of single cell at temperatures between $800^{\circ} \mathrm{C}$ and $650^{\circ} \mathrm{C}$ in dry air. (a) cathode thickness : $3.2 \mu \mathrm{m}$ (b) cathode thickness : $32.5 \mu \mathrm{m}$

성능에 어떻게 영향을 주는지 알아보기 위하여 두께 가 다른 두 단전지의 교류 임피던스를 셀 전위 $0.7 \mathrm{~V}$ 조건에서 측정하였다. Fig. 3의 (a)와 (b) 그래프를 비 교해보면 공기극의 두께가 $3.2 \mu \mathrm{m}$ 인 단전지의 전체 저항이 두께가 $32.5 \mu \mathrm{m}$ 인 단전지에 비해 매우 높게 측정 된 것을 확인 할 수 있다. Table 1에 Fig. 3의 교류 임피던스 그래프의 저항을 정리하였다. 두 단전

Table 1 Resistance extracted from A.C impedance at different temperatures, (a) cathode thick $3.2 \mu \mathrm{m}$ (b) cathode thick $32.5 \mu \mathrm{m}$

\begin{tabular}{c|c|c|c|c}
\hline \hline \multicolumn{2}{c|}{ Temperature $\left({ }^{\circ} \mathrm{C}\right)$} & $\mathrm{R}_{\Omega}\left(\Omega \mathrm{cm}^{2}\right)$ & $\mathrm{R}_{\mathrm{p}}\left(\Omega \mathrm{cm}^{2}\right)$ & $\mathrm{R}_{\text {total }}\left(\Omega \mathrm{cm}^{2}\right)$ \\
\hline \multirow{2}{*}{800} & (a) & 0.30 & 0.25 & 0.55 \\
\cline { 2 - 5 } & (b) & 0.17 & 0.07 & 0.24 \\
\hline \multirow{2}{*}{750} & (a) & 0.47 & 1.12 & 1.59 \\
\cline { 2 - 5 } & (b) & 0.26 & 0.15 & 0.41 \\
\hline \multirow{2}{*}{700} & (a) & 0.66 & 3.35 & 4.01 \\
\hline & (b) & 0.44 & 0.31 & 0.75 \\
\hline \multirow{2}{*}{650} & (a) & 1.01 & 10.28 & 11.29 \\
\hline & (b) & 0.78 & 0.76 & 1.54 \\
\hline
\end{tabular}

(a)
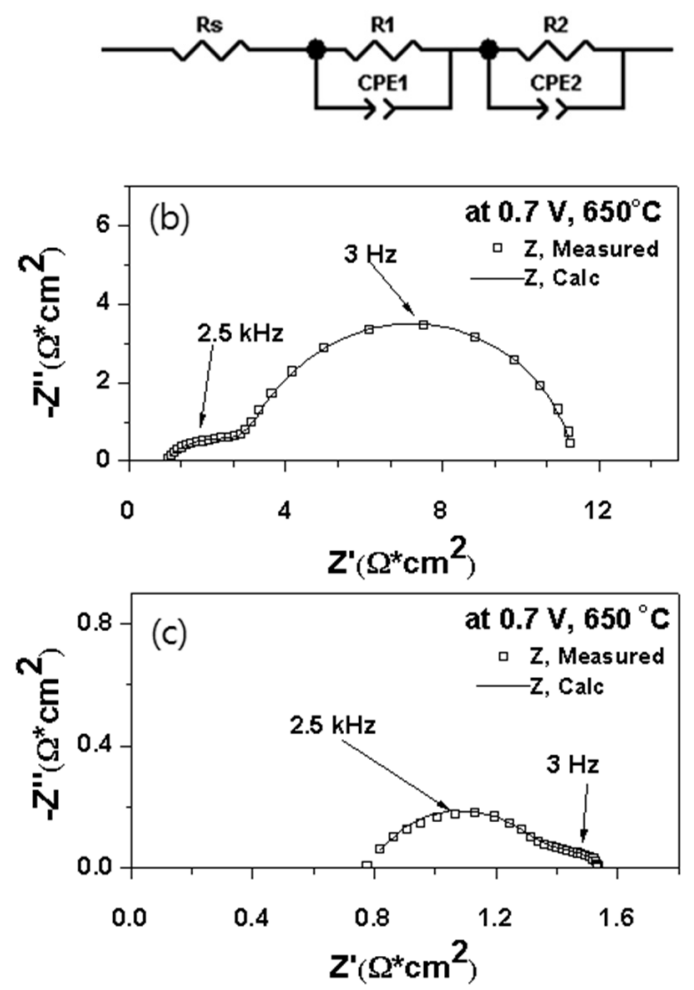

Fig. 4 The equivalent circuit used to fit the electrochemical impedance spectra in at $650^{\circ} \mathrm{C}$ data of Fig. 3, (a)equivalent circuit. Rs : ohmic resistance; R1 : high frequency arc resistance; CPE1 : high frequency arc resistance constant phase element; R2 : Low frequency arc resistance; CPE2 : high frequency arc resistance constant phase element, (b)fitting Nyquist plot about unit cell of cathode thick $3.2 \mu \mathrm{m}$, (c)fitting Nyquist plot about unit cell of cathode thick $32.5 \mu \mathrm{m}$

지의 저항성분을 분석해보면, 각 온도별로 저항의 차 이를 비교했을 때 분극저항 $\left(\mathrm{R}_{\mathrm{P}}\right)$ 에서 차이가 가장 크 게 나타난 것을 확인 할 수 있다. 공기극 두께가 다른 두 단전지의 ohmic 저항값 $\left(\mathrm{R}_{\mathrm{ohm}}\right)$ 차이는 측정온도에 관계없이 약 $0.2 \Omega \mathrm{cm}^{2}$ 이하로 거의 일정했다. 이와 반대로, 분극 저항값의 차이는 $0.18 \Omega \mathrm{cm}^{2}\left(800^{\circ} \mathrm{C}\right)$ 에서 $9.52 \Omega \mathrm{cm}^{2}\left(650^{\circ} \mathrm{C}\right)$ 로 온도가 감소할수록 증가했다. 이 는 공기극의 두께가 $32.5 \mu \mathrm{m}$ 인 단전지는 $800^{\circ} \mathrm{C}$ 에서 $650^{\circ} \mathrm{C}$ 로 온도가 감소했을 때 분극저항이 $0.07 \Omega \mathrm{cm}^{2}$ 에서 $0.76 \Omega \mathrm{cm}^{2}$ 으로 $0.69 \Omega \mathrm{cm}^{2}$ 증가한 반면 공기극 의 두께가 얇은 단전지는 $0.25 \Omega \mathrm{cm}^{2}$ 에서 $10.28 \Omega \mathrm{cm}^{2}$ 로 크게 증가하였기 때문이다. 
Table 2. Result of fitting EIS at $650^{\circ} \mathrm{C}$. ( ) : Error\%

\begin{tabular}{|c|c|c|c|c|c|c|c|}
\hline \multirow{3}{*}{$\begin{array}{l}\text { Cathode } \\
\text { Thickness }\end{array}$} & \multirow{3}{*}{$\begin{array}{c}\text { Rs } \\
\left(\Omega \mathrm{cm}^{2}\right)\end{array}$} & \multicolumn{3}{|c|}{ High Frequency Arc } & \multicolumn{3}{|c|}{ Low Frequency Arc } \\
\hline & & \multicolumn{2}{|c|}{ CPE1 } & \multirow{2}{*}{$\begin{array}{c}\mathrm{R} 1 \\
\left(\Omega \mathrm{cm}^{2}\right)\end{array}$} & \multicolumn{2}{|c|}{ CPE2 } & \multirow{2}{*}{$\begin{array}{c}\mathrm{R} 2 \\
\left(\Omega \mathrm{cm}^{2}\right)\end{array}$} \\
\hline & & $\begin{array}{c}\mathrm{Q} \\
\left(\Omega^{-1} \mathrm{~s}^{\mathrm{n}}\right)\end{array}$ & $\mathrm{n}$ & & $\begin{array}{c}\mathrm{Q} \\
\left(\Omega^{-1} \mathrm{~s}^{\mathrm{n}}\right)\end{array}$ & $\mathrm{n}$ & \\
\hline $3.2 \mu \mathrm{m}$ & $\begin{array}{c}0.95 \\
(2.10)\end{array}$ & $\begin{array}{c}1.98 \cdot 10^{-3} \\
(9.37)\end{array}$ & $\begin{array}{c}0.54 \\
(2.14)\end{array}$ & $\begin{array}{c}2.23 \\
(1.99)\end{array}$ & $\begin{array}{c}4.94 \cdot 10^{-3} \\
(0.61)\end{array}$ & $\begin{array}{c}0.88 \\
(0.33)\end{array}$ & $\begin{array}{c}8.26 \\
(0.49)\end{array}$ \\
\hline $32.5 \mu \mathrm{m}$ & $\begin{array}{l}0.79 \\
(0.7)\end{array}$ & $\begin{array}{c}9.07 \cdot 10^{-4} \\
(13.71)\end{array}$ & $\begin{array}{c}0.72 \\
(2.25)\end{array}$ & $\begin{array}{c}0.57 \\
(3.72)\end{array}$ & $\begin{array}{c}0.23 \\
(11.62)\end{array}$ & $\begin{array}{c}0.55 \\
(9.08)\end{array}$ & $\begin{array}{c}0.20 \\
(11.30)\end{array}$ \\
\hline
\end{tabular}

Fig. 3에서 보는 바와 같이, 공기극의 두께가 32.5 $\mu \mathrm{m}$ 인 단전지는 온도가 감소하여도 고주파영역의 반 원과 저주파영역의 반원 크기 비율이 비교적 일정한 데 비해, 공기극의 두께가 $3.2 \mu \mathrm{m}$ 인 단전지는 낮은 주 파수 영역 $(3 \mathrm{~Hz})$ 의 저항이 온도가 감소할수록 저온 에서 급격하게 증가하는 것을 확인 할 수 있다. 음극 지지형 연료전지에서 높은 주파수 영역의 저항성분 은 연료극의 분극저항과 관련이 있고 낮은 주파수 영역의 저항성분은 공기극의분극저항과 관련이 있는 것으로 알려져 있다. . 또한, 두 단전지는 공기극을 제외하고 전해질 및 음극지지체가 거의 같은 미세구 조를 가지므로 낮은 주파수 영역에서의 저항성분은 공기극의 분극저항과 관련이 있다.

Fig. 4는 Fig. 3의 교류 임피던스 저항 그래프 중 $650^{\circ} \mathrm{C}$ 의 임피던스 곡선으로부터 equivalent circuit model(Fig. 4(a))을 이용하여 fitting한 것이다. 여기서 $\mathrm{CPE}\left(\right.$ Constant Phase Element)는 $Y_{C P E}=Y_{0}(j w)^{n}$ 으로 표현 할 수 있으며, n이 1이면 이상적인 capacitance 이고 $\mathrm{n}$ 이 0 이면 저항을 나타낸다.

Zview2 프로그램의 fitting 기능을 이용하여 구한 $\mathrm{n}$ 값을 Table 2에 정리해 놓았다. 두 단전지의 저항 값은 공기극의 분극저항과 관련된 낮은 주파수 영역 에서 가장 크게 차이가 난다. 공기극의 두께가 $3.2 \mu \mathrm{m}$ 인 단전지의 $\mathrm{n}$ 값은 0.88 로 1 에 가까운 값이다. 즉, 산소의 환원반응에 비해 공기극 물질 내의 산소이온 확산 반응이 느리다는 것을 의미한다. 공기극의 두께 가 $32.5 \mu \mathrm{m}$ 인 단전지의 낮은 주파수 영역 $\mathrm{n}$ 값은 반 무한확산을 의미하는 0.5 에 가까운데, 이는 BSCFZn$\mathrm{LSCF}$ 양극 표면에서 산소의 이온교환반응이 공기극
성능의 제한요소로 작용한다는 것을 의미한다. Nielsen ${ }^{10)}$ 은 산소의 환원 반응이 공기극의 성능을 제한할 때 $\mathrm{n}$ 값이 줄어든다는 것은 보고했다.

산소가 환원되기 위해서는 산소의 흡착, 해리, 전 자의 전도, 산소이온의 전도가 발생하는 삼상계면 (triple phase boundary)이 필요하므로 공기극과 전해 질의 계면에서 산소의 환원 반응이 주로 일어난다. 하지만 이번 연구에 사용된 공기극은 전자 전도성과 이온 전도성을 모두 가지고 있는 혼합 전도성 산화 물이므로, 전해질/전극/공기 삼상계면 뿐만 아니라 공기극 입자 표면에서도 산소의 환원 반응이 일어날 수 있다. 따라서 공기극의 두께가 $32.5 \mu \mathrm{m}$ 인 단전지 는 온도가 감소하여 산소 교환 반응 속도가 줄어도 반응 면적이 충분해서 산소의 환원에 의한 저항이 급격하게 증가 하지 않았지만 공기극의 두께가 $3.2 \mu \mathrm{m}$ 인 단전지는 반응 면적이 부족하므로 산소 교환 반 응 속도의 감소가 산소의 환원에 의한 저항을 크게 증가 시켜 온도 감소에 따른 출력성능 감소를 심화 시켰을 것이다. 즉, 두께가 두꺼운 BSCFZn-LSCF 공 기극의 경우, 넓은 반응면적과 많은 양의 전극물질이 산소 교환반응에 의한 산소이온의 reservoir 역할을 하여 공기극/전해질 계면에서의 반응이 보다 빠른 속 도로 일어날 것으로 예상된다.

공기극의 두께는 단전지의 내구성에도 영향을 주 었다. Fig. 5 는 $800^{\circ} \mathrm{C}$ 에서 시간에 따른 최고 출력 변 화를 공기극 두께별로 측정한 결과이다. 공기극 두 께가 $32.5 \mu \mathrm{m}$ 인 단전지는 약 24 시간이 경과한 후 $1.15 \mathrm{~W} / \mathrm{cm}^{2}$ 에서 $1.13 \mathrm{~W} / \mathrm{cm}^{2}$ 으로 성능이 거의 일정하 게 유지 되었지만 공기극 두께가 $3.2 \mu \mathrm{m}$ 인 단전지는 


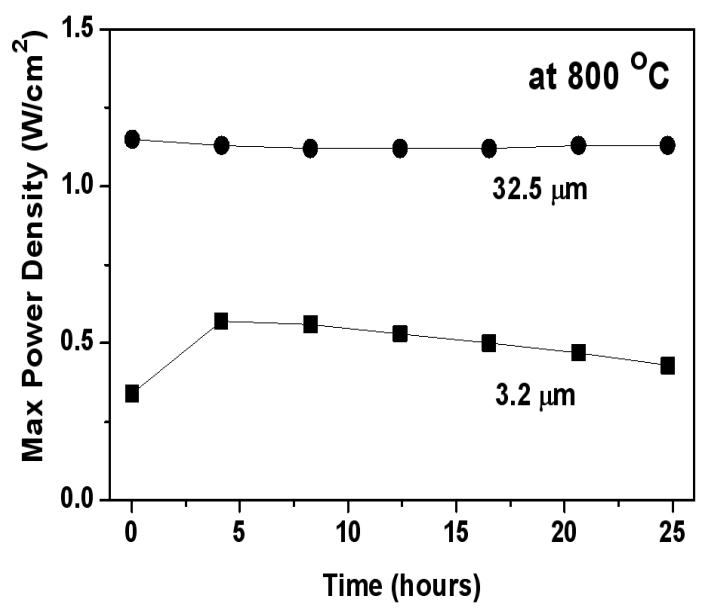

Fig. 5 Long term behaviour of single cell at $800^{\circ} \mathrm{C}$ with different cathode thickness

대략 4시간 동안 성능이 증가한 이후 20 시간 동안 $0.57 \mathrm{~W} / \mathrm{cm}^{2}$ 에서 $0.43 \mathrm{~W} / \mathrm{cm}^{2}$ 으로 약 $25 \%$ 감소하였다. 이러한 성능저하의 원인으로서, 공기중에 미세하게 포함된 $\mathrm{Si}, \mathrm{S}, \mathrm{Cr}$ 에 의한 오염, 전해질과 공기극의 열 팽창률(Thermal Expantion Coefficient, TEC) 차이에 의한 박리현상이 원인으로 알려져 있다 ${ }^{11-14)}$.

Fig. 6 은 $800^{\circ} \mathrm{C}$ 에서 공기극 두께별 교류 임피던 스 저항을 $0.7 \mathrm{~V}$ 에서 24 시간 동안 측정한 결과이다. 공기극 두께가 $3.2 \mu \mathrm{m}$ 인 단전지는 24 시간 경과 후 ohmic 저항과 분극저항이 모두 증가 하였지만, 공기 극 두께가 $32.5 \mu \mathrm{m}$ 인 단전지는 저항의 변화가 거의 없 었다. 본 연구에서 사용된 BSCFZn 공기극은 열팽창 율이 비교적 큰 물질이므로, 전해질과 공기극이 TEC 차이에 의해서 전해질로부터 분리되면 ohmic 저항과 분극저항이 모두 증가한다 ${ }^{12)}$. 공기극의 두께가 다른 두 단전지의 전해질과 공기극은 각각 같은 물질을 사용했지만, 공기극 두께가 $3.2 \mu \mathrm{m}$ 인 단전지는 두께 가 두꺼운 단전지에 비해 이러한 박리현상이 쉽게 일 어날 수 있다. 열팽창율 차이에 의한 전극의 박리는 전해질/공기극 계면에서의 이온 확산을 저해하게 된 다. 이는 Fig. 4의 fitting 결과에서 두께 $3.2 \mu \mathrm{m}$ 공기 극의 경우 $\mathrm{n}$ 값이 0.88 로 높은 값을 보이는 결과와 일치한다. 이에 반해, $32.5 \mu \mathrm{m}$ 두께의 공기극은 안정

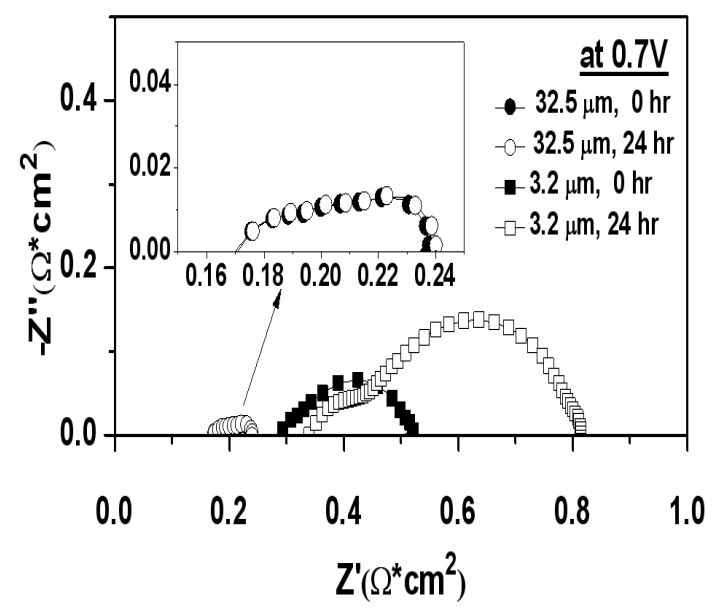

Fig. 6 Impedance spectra of single cell as time passed

한 계면에 의해 작은 저항값을 보이며, 전극 두께가 증가함에 따라 가스의 확산 및 이온교환 반응이 제 한됨에 따라 Warburg element의 거동 $(\mathrm{n}=0.55)$ 을 보 이는 것으로 생각된다.

\section{4. 결 론}

혼합전도성 산화물을 공기극으로 사용했을 경우, 공기극의 두께가 충분하지 못하면 작동온도가 낮아 짐에 따라 출력이 크게 감소했다. 두께가 작은 단전 지로부터 교류 임피던스를 측정하여 분석한 결과, 온 도가 낮아질수록 낮은 주파수의 분극 저항이 급격히 증가하였다. 또한, 단전지의 내구성 테스트 결과는 얇은 두께의 공기극의 경우 시간이 갈수록 ohmic 저 항과 분극저항이 동시에 증가하는 것을 나타내었다. 두께가 얇은 공기극에서 일어난 저항증가는 공기극 의 높은 열팽창율에 의해 전해질/공기극 계면에서 일 어난 delamination에 의한 것으로 생각된다.

\section{후 기}

이 논문은 2012년도 정부(교육과학기술부)의 재원 으로 한국연구재단 기반형 녹색기술 융합연구사업의 지원을 받아 수행된 연구임. 


\section{참 고 문 헌}

1. Tsepin Tsai, Erica Perry, Scott Barnett, "Lowtemperature solid-oxide fuel cells utilizing thin bilayer electrolytes", Journal of the Electrochemical Society, Vol. 144, No. 5, L130-L132, 1997.

2. Erica Perry Murray, Tsepin Tsai, Scott A Barnett, "Oxygen transfer processes in ( $\mathrm{La}, \mathrm{Sr}) \mathrm{MnO}_{3} / \mathrm{Y}_{2} \mathrm{O}_{3}$ stabilized $\mathrm{ZrO}_{2}$ cathodes: an impedance spectroscopy study", Solid State Ionics, Vol. 110, No. 3-4, 235-243, 1998.

3. Andreas Mai, Vincent A.C. Haanappel, Sven Uhlenbruck, "Ferrite-based perovskites as cathode materials for anode-supported solid oxide fuel cells", Solid State Ionics, Vol. 176, No. 15-16, 1341-1350, 2005.

4. Brian C.H. Steele, Joong-Myeon Bae, "Properties of $\mathrm{La}_{0.6} \mathrm{Sr}_{0.4} \mathrm{Co}_{0.2} \mathrm{Fe}_{0.8} \mathrm{O}_{3-\mathrm{x}}$ (LSCF) double layer cathodes on gadolinium-doped cerium oxide (CGO) electrolytes: II. Role of oxygen exchange and diffusion", Solid State Ionics, Vol. 106, No. 3-4, 255-261, 1998.

5. Jae Layng Park, Tak Hyoung Lim, Seung Bok Lee, Seok Joo Park, Dong Ryul Shin, Kyoo Seung Han, Rak Hyun Song, "Synthesis and Characterization of LSCF/CGO Composite Cathode for SOFC", The Korean Hydrogen \& New Energy Society, Vol. 21 No. 1, 19-25, 2010.

6. Hiroshi Fukunaga, Manabu Ihara, Keiji Sakaki, "The relationship between overpotential and the three phase boundary length", Solid State Ionics, Vol. 86-88, Part 2, 1179-1185, 1996.

7. Ryan O’Hayre, David M. Barnett, Prinz, Fritz B. Prinz, "The triple phase boundary a mathematical model and experimental investigations for fuel cells", Journal of the Electrochemical Society,
Vol. 152, No. 2, 2005, A439-A444, 2005.

8. Xiaohua Deng, Anthony Petric, "Geometrical modeling of the triple-phase-boundary in solid oxide fuel cells", Journal of Power Sources, Vol. 140, No. 2, 297-303, 2005.

9. Sung Pil Yoon, Jonghee Han, Suk Woo Nam, "Performance of anode-supported solid oxide fuel cell with $\mathrm{La}_{0.85} \mathrm{Sr}_{0.15} \mathrm{MnO}_{3}$ cathode modified by sol -gel coating technique", Journal of Power Sources, Vol. 106, No. 1-2, 160-166, 2002.

10. Jimmi Nielsen, Torben Jacobsen, MarieWandel, "Impedance of porous IT-SOFC LSCF:CGO composite cathodes", Electrochimica Acta, Vol. 56, No. 23, 7963-7974, 2011.

11. Edith Bucher, Werner Sitte, "Long-term stability of the oxygen exchange properties of $(\mathrm{La}, \mathrm{Sr})_{1-\mathrm{z}}$ $(\mathrm{Co}, \mathrm{Fe}) \mathrm{O}_{3-\delta}$ in dry and wet atmospheres", Solid State Ionics, Vol. 192, No. 1, 7313-7317, 2011.

12. Kwangjin Park, Sungoh Yu, Joongmyeon Bae, Hyungsop Kim, Yoonki Ko, "Fast performance degradation of SOFC caused by cathode delamination in long-term testing", International Journal of Hydrogen Energy, Vol. 35, No. 16, 86708677, 2010.

13. J. Andreas Schuler, Zacharie Wuillemin, Aïcha Hessler-Wyser, Clément Comminges, Nadia Yousfi Steiner, Jan Van herle, "Cr-poisoning in (La,Sr) $(\mathrm{Co}, \mathrm{Fe}) \mathrm{O}_{3}$ cathodes after $10,000 \mathrm{~h}$ SOFC stack testing”, Journal of Power Sources, Vol. 211, 177-183, 2012.

14. Fangfang Wang, Katsuhiko Yamaji, Do-Hyung Cho, Taro Shimonosono, Haruo Kishimoto, Manuel E. Brito, Teruhisa Horita, Harumi Yokokawa, "Effect of strontium concentration on sulfur poisoning of LSCF cathodes", Solid State Ionics, Vol. 225, 157-160, 2012. 